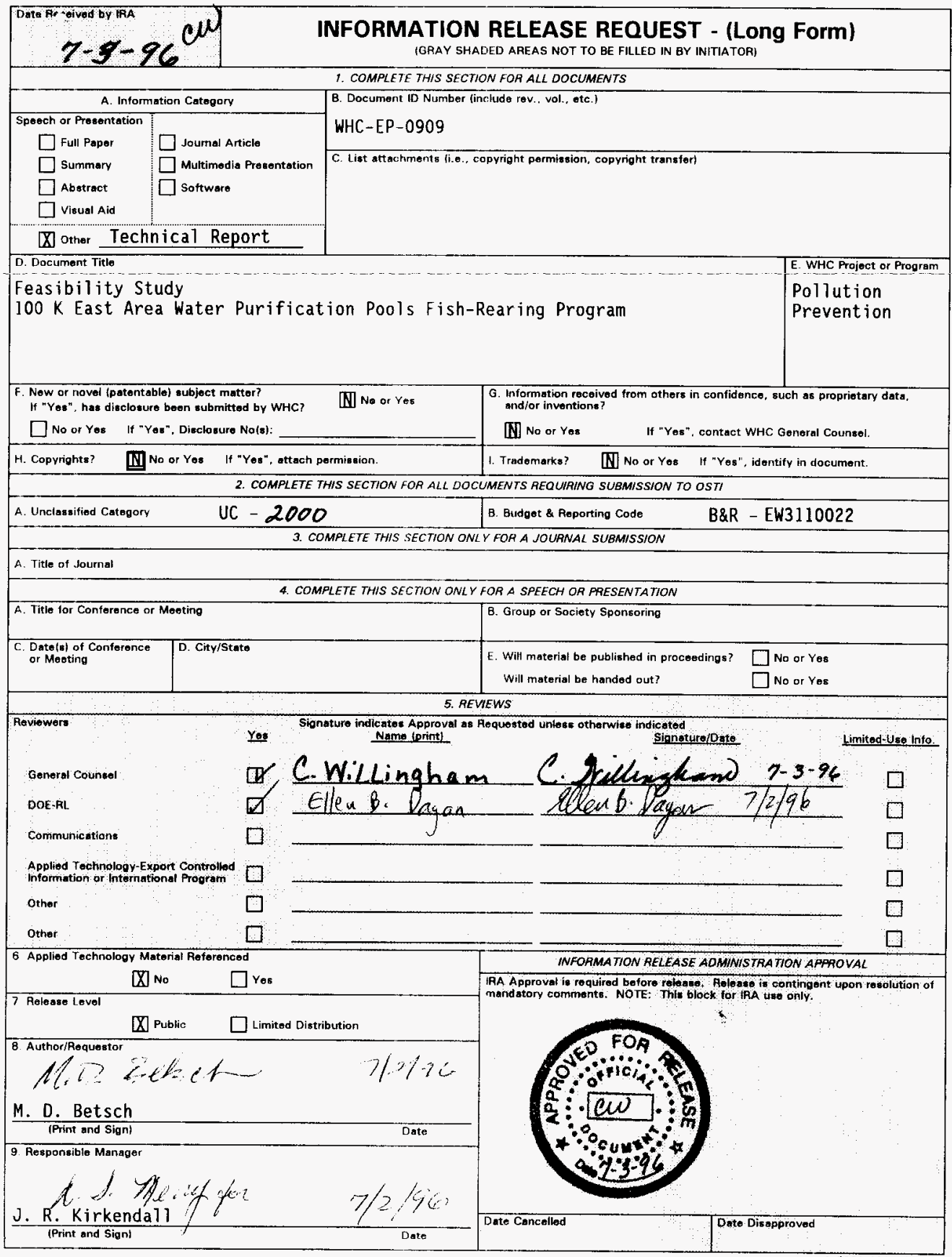


WHC-EP-0909

Document ID Number

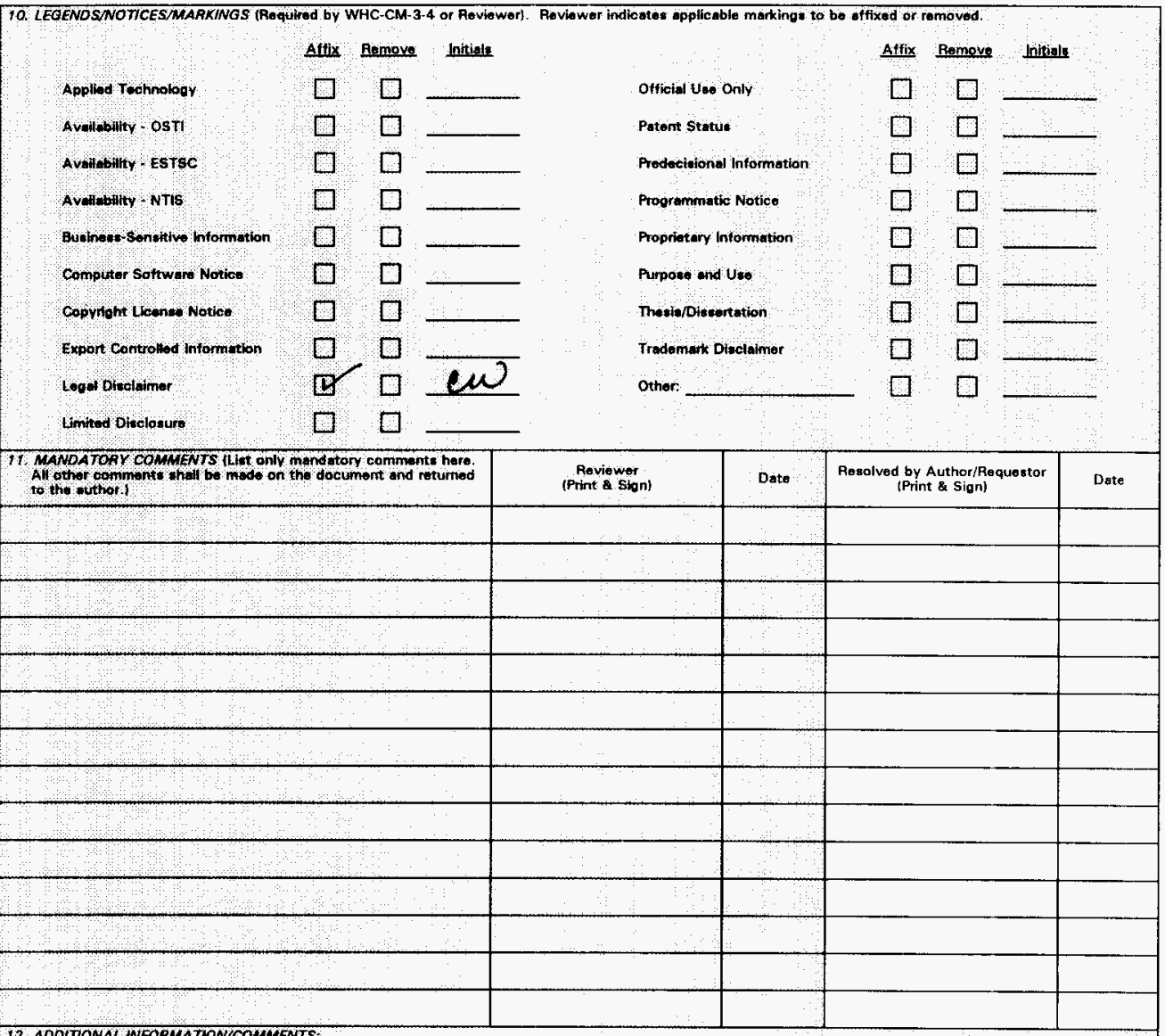




\section{RELEASE AUTHORIZATION}

\section{Document Number: WHC-EP-0909}

Document Title: Feasibility Study look East Area Water Purification Pools Fish-Rearing Program

Release Date: $\quad 7 / 3 / 96$

This document was reviewed following the procedures described in WHC-CM-3-4 and is:

APPROVED FOR PUBLIC RELEASE

WHC Information Release Administration Specialist:

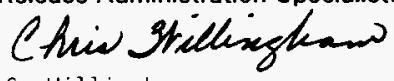

C. Willingham

$7 / 3 / 96$ 


\section{Feasibility Study $100 \mathrm{~K}$ East Area Water Purification Pools Fish-Rearing Program}

Prepared for the U.S. Department of Energy

Assistant Secretary for Environmental Management

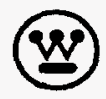

U.S. Department of Energy under Contract DE-ACO6-87RL 10930

Approved for public release; distribution is unlimited 


\section{Feasibility Study $100 \mathrm{~K}$ East Area Water Purification Pools Fish-Rearing Program}

M. D. Betsch

R. A. Huckfeldt, Jr.

Westinghouse Hanford Company

M. A. Dipiazza

Chatham College

W. S. Dunnivant

ICF Kaiser Hanford Company

Date Published

July 1996

Prepared for the U.S. Department of Energy Assistant Secretary for Environmental Management

\section{(2) Westinghouse P.O Box 1970 \\ Hanford Company Richland, Washington}

Management and Operations Contractor for the

U.S. Department of Energy under Contract DE-AC06-87RL 10930

Approved for public release; distribution is unlimited 
LEGAL DISCLAIMER

This report was prepared as an account of work sponsored by an agency of the United States Government. Neither the United States Government nor any agency thereof, nor any of their amployees, nor any of their contractors, subcontractors or their employees, makes any warranty, express or implied, or assumes any legal liability or responsibility for the accuracy, completeness, or any third party's use or the results of such use of any information, apparatus, product, or process disclosed, or represents that its use would not infringe privately owned rights. Reference herein to any specific commercial product, process, or service by trade name, trademark, manufacturer, or otherwise, does not necessarily constitute or imply its endorsement, recommendation, or favoring by the United States Government or any agency thereof or its contractors or subcontractors. The views and opinions of authors expressed herein do not necessarily state or reflect those of the United States Government or any agency thereof.

This report has been reproduced from the best available copy Available in paper copy and microfiche.

Available to the U.S. Department of Energy and its contractors from

U.S. Department of Energy

Office of Scientific and Technical Information (OST)\}

P.O. Box 62

Oak Ridge, TN 37831

(615) $576-8401$

Available to the public from the U.S. Department of Commerce National Technical Information Service (NTIS)

5285 Port Royal Road

Springfield, VA 22161

(703) $487-4650$

Printed in the United States of Americe

DISCLM-1.CHP (8-95) 


\title{
Feasibility Study 100 K East Area Water Purification Pools Fish-Rearing Program
}

\author{
Design Study of Sand Filters and Related Structures
}

\section{Introduction}

As part of the feasibility study, a design analysis was conducted to determine the usefulness of the existing sand filters and associated media for reuse. The sand filters which were studied for potential reuse are located on the northern end of the 100-K East Area water filtration plant on the Hanford Site. This plant is located about one-half mile from the Columbia River. The sand filters were originally part of a system which was used to provide cooling water to the nearby plutonium production K Reactors. This Cold War operation took place until 1971, at which time the K Reactors were closed for eventual decontamination and decommissioning.

Recently, it was decided to study the concept of putting the sand filter structures back into use for fish-rearing purposes. Because the water that circulated through the water purification pools (K Pools) and associated sand filters was clean river water, there is little chance of the structures being radioactively contaminated. To date, separate $K$ Pools have been used for raising a variety of cold water fish species, including white sturgeon and fall chinook salmon, as well as for providing potable water to the $100 \mathrm{~K}$ Area of the Hanford Site for fire and service water purposes.

\section{Proposal}

A conceptual project consists of placing eight 8-ft diameter tanks and two 20-ft diameter tanks on the floor of an empty $K$ Pool. The smaller tanks will be used to rear various warm-water fish, such as channel catfish, walleye, large mouth bass, small mouth bass, crappie, and blue gill. The tank volume for each of these tanks is 100 cubic feet. The larger tanks will rear white sturgeon. The tank volume for each of these tanks is 1250 cubic feet.

Because all fish species to be used for this project are warm-water species, the water will need to be maintained between 60 and 80 degrees Fahrenheit year round.

The water flow pattern for this project is envisioned as follows (See Figure 1): River water is initially pumped up two 5-ft diameter pipes from the Columbia River. This water travels through the center of the KE filtration plant until it reaches the south end, where each of the pipes branch into three smaller ones. The smaller pipes carry the water to one of six $K$ Pools via a distribution flume. As water fills a $K$ Pool, it overflows the weir wall at the north end of the pool and flows into the $K$ Pool discharge flume. By valve control, water is either directed into the effluent outfall or the nearest gullet (a holding tank). As the gullet fills, the water flows into troughs and onto the sand filter. 
The concept being investigated is to use a sand filter as a header pool, where water will be heated before being circulated to the fish-rearing tanks located on the floor of an adjacent empty $K$ Pool. After the water flows to the rearing tanks by the force of gravity, it will then be pumped back to the sand filter volume for treatment and then reheated.

\section{Existing Structures and Possible Modifications}

The structures in question consist of the $K$ Pools, the sand filters, the flumes connecting the two, and the gullets. Each $K$ Pool is constructed of unlined concrete, and is $351 \mathrm{ft}$. long and $127 \mathrm{ft}$. wide. A K Pool can hold about 6.5 million gallons of water. The $K$ Pool used to fill the sand-filter header volume should have the seams caulked before filling, and accumulated dirt and debris will need to be cleared. The flume from a $K$ Pool to a sand filter, which runs in a west-to-east direction, is $4 \mathrm{ft}$. 4 inches high and 3 $\mathrm{ft}$. 9 inches wide. This flume opens by valve action into another flume below it, which empties into the gullets. The latter flume is called the filter distribution flume and is $5 \mathrm{ft}$. high and $6 \mathrm{ft} .6$ inches wide. The gullet is located between sand filters and has the function of settling the water before it flows onto the sand filter material. This prevents the filter layers from being disrupted. The gullet measures $49 \mathrm{ft}$ long, $11 \mathrm{ft}$. wide, and $14 \mathrm{ft} .8$ inches deep, with a water volume of approximately 7977 cubic feet. A sand filter measures $50 \mathrm{ft}$. long, $25 \mathrm{ft}$. wide, and $8 \mathrm{ft}$. 7 inches deep, with a water volume of approximately 10,875 cubic feet. The total sand-filter header volume is thus 18,853 cubic feet or about $141,000 \mathrm{gal}$.

All of the valves in these structures are believed to be in working condition, but may need maintenance before they can be reused. Some modifications within the sand filter may be needed for this project. Because the sand filter was not originally designed as a water-holding volume, some valves may need to be added to prevent flow into the clearwel1, a storage system that holds water for use at the 100-K Area that cannot be contaminated with fish water. The backwash pipe located near the bottom of the sand filter provides access to the clearwell for the filtration plant. Therefore, a blind flange can be inserted into the backwash pipe to ensure that contamination of the clearwell does not take place.

Other modifications that may be needed to carry out the conceptual project are the addition of pumps and piping to create a closed circulation pathway to the fish-rearing tanks and back. The water will flow from the sand filter volume to the individual fish-rearing tanks by gravity flow. Recommended piping will likely consist of 3 to 4 inch diameter PVC pipe. The water will then be circulated through the tanks and pumped back to the filter volume for reheating and cleaning. The recommended pump for this step will likely be a 12 psi 5 horsepower centrifugal pump. This pump will circulate 600 gallons/minute, which will be more than enough for required purposes.

The only potential challenge for this concept is the possible need to backwash the sand filter medium. Although there are no current plans for this procedure, it should be recognized that backwashing the filter may require extensive modifications to the system. The original backwash lines have been capped and the pumps removed, so it will be impossible to complete the procedure as the system currently exists. Another issue regarding this potential challenge of backwashing may be disposal of the backwash discharge 
water. Regulations prohibit discharging backwash into the Columbia River, so additional piping and pumps will have to be constructed to route the water to a settling basin. Such modifications could be extremely costly. Therefore, alternative cleanup methods may have to be explored.

\section{Design Study Conclusions}

This concept has the potential of being a highly successful one. Most of the existing structures needed for its implementation are in good working condition. With a well designed waste water treatment system, backwashing should not become a problem. Putting the proposed fish-rearing concept into use could be highly beneficial to the area's economy. In addition, it would also provide a purpose for these currently non-useful structures. Due to the success of previous fish-rearing projects similar in complexity to this one and the need for few major modifications, it can be concluded that the concept may be possible to implement with relative ease and should work well.

\section{Baseline Energy Usage Required}

Since this project is in design, there was no baseline information available in which to compare alternatives against. Therefore, liquid propane was used as the baseline which is the standard method used on the Hanford site. The baseline information included heating approximately 140,000 gallons of water in a header pool and maintaining the temperature between 60-80 degrees Fahrenheit for optimal fish growth. It was estimated that approximately 450,000 BTU's/hour would be required.

Area $=\mathrm{LW}$

$\mathrm{L}=$ length

$W=$ width

Volume $=7.5 \mathrm{gal} / \mathrm{ft}^{3} \times$ Area $\times$ Average Depth

1. Pool water capacity is 140,000 gallons

2. Desired heat pickup time 168 hours (1 week)

3. Desired pool temperature is 70 degrees $F$

4. Average pool water temperature of the coldest month is 37.2 degrees $F$

5. The sand filter is $1,250 \mathrm{ft}^{2}$

6. Average yearly ambient temperature is 53.1 degrees $F$

$q_{1}=8.33 V\left(t_{f}-t_{i}\right) /-0-$

where

$q_{1}=$ pool heat-up rate, Btu/h

$8.33=$ density of water, $1 \mathrm{~b} / \mathrm{gal}$

$V=$ pool volume, gal

$t_{f}=$ desired temperature

$\mathbf{t}_{j}=$ initial temperature of pool, degrees $F$

$-0-=$ pool heat-up time, hours 
$q^{1}=(8.33) 140,000$ gallons $(70$ degrees $F-37.2$ degrees $F) / 168$

$=(1,166,200)(32.8) / 168$

$=227,686 \mathrm{Btu} / \mathrm{h}$

$q_{2}=10.5 A\left(t_{p}-t_{a}\right)$

$q_{2}=(10.5)\left(1,250 \mathrm{ft}^{2}\right) \quad(70$ degrees $F-53.1$ degrees $F)$

$=(13,125)(16.9)$

$=221,812 \mathrm{Btu} / \mathrm{h}$

where

$q_{3}=$ heat loss from pool surface, Btu

10.5 = surface heat transfer coefficient, Btu/h $\times \mathrm{ft}^{2} \times$ degrees $F$

$A=$ pool surface area, $\mathrm{ft}^{2}$

$t_{0}=$ pool temperature, degrees $F$

$t_{a}=$ ambient temperature, degrees $F$

$q_{t}=q_{1}+q_{2}$

$q_{t}=227,686+221,812$

. $449,498 \mathrm{Btu} / \mathrm{h}$

Note: These heat losses assume a wind velocity of 3 to $5 \mathrm{mph}$.

Since the last equation $\left(q_{t}=q_{1}+q_{2}\right)$ applies to the coldest monthly temperatures, the calculated results may not be economical. Therefore, a value of $1 / 2$ the surface loss plus the heat-up value yields a more viable heater output figure. The heater input then equals the output divided by the efficiency of the fuel source.

\section{Study Method}

Two analytical methods common to the Hanford site were utilized for identifying the most energy efficient opportunity available. The two methods used were the Pollution Prevention Opportunity Assessment (PPOA) model and the Building Life Cycle cost (BLCC) program.

The PPOA model is an approved U.S. Department of Energy method for identifying inputs and outputs of a particular activity and determine opportunities for waste minimization and energy savings. The Assessment consists of five worksheets for analyzing various opportunities through a cost benefit analysis.

The information generated through the P2OA process was used to input into the Building Life Cycle Cost computer program. The report generated a list of each opportunity indicating the opportunity with the lowest payback. Both models concluded with the same recommendation for implementation--reuse the 
solar water heater from the 2750 roof. 
WORKSHEET 1

TEAM AND ACTIVITY DESCRIPTION

Date $04 / 23 / 96$

P2OA ID Code Energy-1

Facility $\mathrm{K}$ Basin Pools

Activity Water Heating Methods for Raising Warm Water Fish Species

Team Members (*Leader)

Telephone

MSIN

Mary Betsch

$372-1627$

B3-28

Dan Herborn

$373-0087$

H6-06

Steve Dunnivant

$373-3279$

G3-04

Bruce Anderson

373-0087

Rick Huckfeldt

$372-3212$

H6-06

Michelle DiPiazza

372-0314

Description of Activity to be Examined in this P2OA

Existing sand filters adjacent to the KE-Pools will be used as a self-insulated warmwater reservoir to rear fish species for a commercial market project. A conceptual project consists of placing eight 8-foot diameter (100 cubic ft) tanks and two 20-foot ( 1250 cubic $\mathrm{ft}$ ) tanks on the floor of an existing, empty KE-Pool. The water must be maintained between 60 - 70 degrees fahrenheit for optimal fish growth.

The sand filter will be utilized as the header pool where water will be heated before being circulated to the fish-rearing tanks located on the floor of the KE-Pool. After the water flows to the rearing tanks via the force of gravity through 5-6 inch diameter insulated PVC pipe, it will be pumped back to the sand filter to be treated and reheated. The water will flow at 320 gallons per minute between the tanks.

The dimensions of the sand filter are $50 \mathrm{ft} 1 \mathrm{ong}, 25 \mathrm{ft}$ wide, and $8 \mathrm{ft}$ deep.

Calculations will be based on a 20 year history of Columbia River water temperature and will be adjusted with approximately $20 \%$ more heat available to the system than is necessary to provide for possible loss.

The assessment process is to determine the most energy efficient method to heat approximately 140,000 gallons of water in the header pool to the required temperature range. 
WORKSHEET 2

ACTIVITY FLOW DIAGRAM

Date 04/24/96 P2OA ID Code Energy-1 Facility K Basin Pools

Activity Water Heating Methods for Raising Warm Water Fish Species

\begin{tabular}{|c|}
\hline \multicolumn{2}{|c|}{$\begin{array}{c}\text { Chemical and } \\
\text { Radioactive Inputs }\end{array}$} \\
\hline Name Quantity \\
\\
\\
\end{tabular}

\begin{tabular}{|lr|}
\hline \multicolumn{2}{|c|}{ Material Inputs } \\
\hline Name & Quantity \\
Blue Gill-2.000 oa & $12 \mathrm{~kg}$ \\
Channal Catfish-2,000 os & $12 \mathrm{~kg}$ \\
Croppio-2,000 oa & $12 \mathrm{~kg}$ \\
Large Mouth Bass-2,000 ea & $12 \mathrm{~kg}$ \\
Small Mouth Bass 2.000 os & $12 \mathrm{~kg}$ \\
Sturgoon-389 oa & $2,646.70 \mathrm{~kg}$ \\
Wolloye-2,000 es & $12 \mathrm{~kg}$ \\
Row Woter-Cold & $529.96 \mathrm{~m}$ \\
\hline
\end{tabular}

\begin{tabular}{|lr|}
\hline \multicolumn{2}{|c|}{ Energy Inputs } \\
\hline Name & Quantity \\
Pump-5 hp & $105.74 \mathrm{KJ}$ \\
& \\
& \\
& \\
& \\
\hline
\end{tabular}

\begin{tabular}{|l|}
\hline \multicolumn{1}{c|}{ Activity } \\
\hline Activity Time Period: \\
1 Year \\
\hline
\end{tabular}

Outputs include:

Solid (s)

Liquid (I)

Air (a)

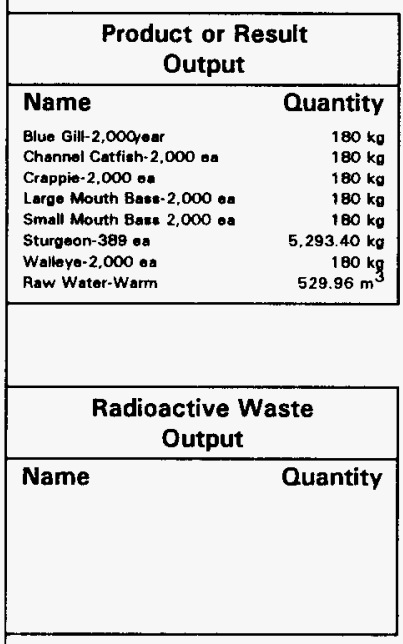

\begin{tabular}{|l|}
\hline \multicolumn{2}{|c|}{$\begin{array}{c}\text { Hazardous Waste } \\
\text { Output }\end{array}$} \\
\hline Name \\
\\
\\
\\
\\
\end{tabular}

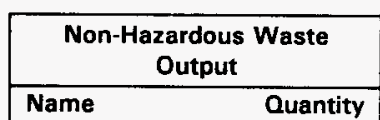

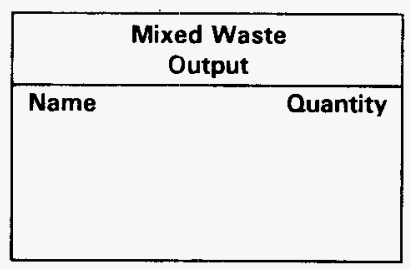

\begin{tabular}{|lr|}
\hline \multicolumn{2}{|c|}{ Other } \\
\hline Name & Quantity \\
Algae & N/A \\
Ammonia & N/A \\
Nitrogon & $189 \mathrm{~kg}$ \\
Pothogens & N/A \\
PPosphorus & $31.50 \mathrm{~kg}$ \\
Solid Fish Foces & N/A \\
\hline
\end{tabular}

Total Input mass $\approx$ Total Output mass $\quad \mathrm{kg} \ln \approx \mathrm{kg}$ Out 
WORKSHEET 3

POLLUTION PREVENTION OPPORTUNITY DESCRIPTION

Date 04/24/96 P20A ID Code Energy-1 Facility K Bas in Pools

Activity Water Heating Methods for Raising Warm Water Fish Species

P2O No. 1

P2O Title Cube Tumbleweeds and Noxious Weeds as Feed to a Small Biomass Boiler

\section{Current Practice}

Because this project is in design, there is no current practice. Therefore, Liquid Propane (LP) will be used as the current practice (baseline) to heat approximately 140,000 galions of water in the header pool and maintain the temperature between 60-70 degrees Fahrenheit for optimal fish growth. It is estimated that approximately 449,498 BTU's/hour will be required.

\section{Recommended Action}

Shred and cube tumbleweeds, nuisance weeds (Tumble Mustard) and noxious weeds (Yellow Starthistle, Russian Knapweed). The cubes will be used as feed to a small biomass boiler which will in turn heat water to maintain the required temperature.

Noxious weeds include plant species specified at the Federal, State, or County level as noxious. Yellow Starthistle and Russian Knapweed are legal noxious weeds whereas Tumble Mustard and Tumbleweeds are simply nuisance weeds.

Tumbleweed Collection Process (Scott Angerman, ICF. KH)

In an effort to keep tumbleweeds from blowing into radioactive zones, Hanford has established an aggressive tumbleweed pick up program for non-radioactive tumbleweeds. Tumbleweeds are collected from various locations onsite using a pitch fork and a garbage truck. The tumbleweeds are dumped into inert pits and left for decomposition. Additionally, tumbleweeds which accumulate along fence lines and barriers are routinely mulched and left in place using a tumbleweed mulching machine.

Shredding/Grinding Process (Colton Equipment, Inc. and Johrnie Young, ICF KH)

There are two possible alternatives to consider with regard to shredding the tumbleweed and noxious weeds prior to cubing. One scenario would be to bring the material to a central location and process through a stationary shredder. The other would be to use a mobile unit and shred the weeds in the field. The stationary system would include an in feed conveyor, shredder, discharge conveyor and controls. The mobile system would be comprised of a trailer mounted shredder equipment with diesel power and a discharge conveyor. Both of these types of shredders can usually be purchased in good used condition for a significant savings.

Additionally, there are two grinders available onsite which can be utilized 2-3 times per year. The grinders are available through ICF Kaiser, Johnnie Young. Utilizing the grinders available onsite is recommended.

Cubing System (Warren and Baerg Manufacturing. Inc.)

The fuel cubes produced have characteristics similar to those of coal or hog fuel and 


\section{POLLUTION PREVENTION OPPORTUNITY ASSESSMENT \\ WORKSHEET 3 \\ POLLUTION PREVENTION OPPORTUNITY DESCRIPTION (Continued)}

can be used in most industrial boilers. Utilizing these materials not only reduces the volume of waste going to the landfills, it creates an on-going source of energy.

The fuel cubes can be 1-1/4" square, I" square, or 1 " round. They break off in lengths of 1" to 3". Feed stock (noxious weeds and tumbleweeds) need only be shredded to 1$1 / 2^{\prime \prime}-2 "$, reducing the horsepower demand for shredding equipment.

Warren and Baerg Manufacturing has successfully cubed agriculture waste such as wheat Straw, Rice Straw, Oat Straw, Flax, Water Hyacinths, and Sudan Grass which have a moisture content between $8 \%$ and $18 \%$, a bulk density between 25 and 34 pounds per cubic foot, and produce 4.5 to 12 tons per hour.

The cuber (Model 250 and Model 250W) has a $200 \mathrm{hp}$ motor and can operate at 6 to 8 tons per hour. The cuber has 66 individual die blocks and one 22" diameter adjustable press whee]. There is no cutting device. Rather, a cub breaker continuously sizes the cubes and the length of the cube can be adjusted with the setting of the cube breaker.

Materials enter the die chamber and are forced through the die at 7,500 to 10,000 PSI, the dwell time is 6 to 8 seconds.

The Basic 200 Cubing System manufactured by Warren and Baerg Manufacturing, Inc. includes a Metering Bin, Model 200 Cuber, and Conveying System all designed to the following specifications:

-open Metering Bin

$6^{\prime}$ wide $\times 32^{\prime}$ long

Two rake in doffer, each with $5 \mathrm{hp}$ motor

$.5 \mathrm{hp}$ floor drive

Fines return auger

-Infeed Auger

16" Auger

$10 \mathrm{hp}$ electric motor and gear reducer

Auger flights are $1 / 4$ " thick

-Magnet and Transition Chute

At infeed auger to mixer auger

Industrial plate magnet

-Standard Mixer

$22^{\prime \prime} \times 12^{\prime}$

5 hp shaft mount reduction gearhead drive

Six $110 \vee$ solenoid on/off valves

-Mode1 200 Cuber

18 " plate magnet in infeed chute

Heavy duty right hand end cap

Frame and trolley for die ring removal

One set of dies

Rexnord gearbox - Saturn

$200 \mathrm{hp}$ electric motor - TEPC, $1800 \mathrm{rpm}, 460 \mathrm{v}, 3$ phase, $60 \mathrm{~Hz}$

-Takeaway Conveyor 
$15^{\prime \prime}$ wide $\times 30^{\prime}$ long

Electric motor and gear reducer

-Cyclone, Blower and Ducting

Two collection points (cuber and metering bin fines auger)

Includes ducting, fittings, hangers and hoses

It is important to note that most materials will not store as well over $12 \%$ moisture content.

\section{Boiler (Hellons)}

The steam generating system consists of a Wellons' 10,000 PPH combination firetube/watertube steam boiler, model WFIC4.5, operating at 30 psig and saturated temperature. Steam from the boiler system is piped to a heat exchanger where energy is transferred to the water stream of the main process. The equipment includes:

-Metering surge bin

-One Wellons' cell

-I.D. \& F.D. Fans

-Ash handling system

-Boiler pressure parts and casing

-Feedwater storage tank and pumps

-Boiler plant piping, valves, and associated equipment

-Computerized control system

- Process piping to and from the heat exchanger (100 linear ft.)

-Cell feed screw

- Insulation and refractory

- Multiple cone collector

-Air and gas ducting

-Boiler trim

-Decks and catwalks

- Motor control center

-Steam to process heat exchanger

The cyclo-blast furnace cell has water-cooled grates and alumina plastic refractory cell lining. The combustion air is provided by a forced draft fan. An induced draft fan pulls exhaust gases through the boiler section and multiple cone collector and exhausts into an uptake stack.

The feedwater system includes two motor driven feedwater pumps, one gratewater pump, water level controls, feedwater storage tank, and associated piping.

A multiple cone collector is provided in the boiler exhaust system for removal of particulate from exhaust gases. The multiple cone discharges automatically via a rotary air lock valve to the receiver. Ash deposits in the fuel cell and the boiler dropout are removed manually.

Potential exists to use a bottom feed boiler which would accept shredded feed stock from 1" - 3" in size. The bottom feed boiler is the same cost as the top feed model explained above. 


\section{POLLUTION PREVENTION OPPORTUNITY ASSESSMENT \\ WORKSHEET 3 \\ POLLUTION PREVENTION OPPORTUNITY DESCRIPTION (Continued)}

Heat Exchanger (Brad Thompson at The Brad Thompson Company)

The VICARB heat exchanger consists of a plate pack of a calculated number of embossed plates with perimeter gaskets clamped securely between two thick carbon steel plates by means of tie rods. The plates have openings at corners to direct process and service fluid flows through the passageways between plates. Fluids flow alternately between every other plate in order to achieve correct heat transfer almost always in true counter current condition.

\section{Calculation of Waste Reduction and/or Energy Savings}

Annual quantity of LP required $=5,256$ gallons

The quantity of LP necessary to maintain the temperature required is approximately .6 gallons/hour running at $90 \%$ efficiency.

$.6 \mathrm{gatlons} /$ hour $\times 24$ hours $/$ day $\times 365$ days $/$ year $=5,256$ gallons $/$ year

Annual quantity of tumbleweeds/noxious weeds necessary to heat water to desired temperature $=1,680$ tons

Total Annual $=7$ tons $/ \mathrm{hr} \times 240 \mathrm{hrs}=1,680$ tons or $3,360,000$ pounds.

TOTAL WASTE REDUCTION

5,256 gallons LP and 1,680 tons tumbleweeds/noxious weeds

\section{Calculation of Annual Cost Savings}

Costs:

\section{Annual electricity cost to run boiler $=\$ 319.46$}

The cost of electricity in the Tri-Cities is currently $\$ .03 / \mathrm{Kwh}, 10,000 \mathrm{PPH}$, operating at $30 \mathrm{psig}$ and saturated temperature.

$85 \mathrm{HP} \times 70 \%=59.5 \mathrm{HP} \times .7457 \mathrm{Kw} / \mathrm{hp}=44 \mathrm{Kwh} \times \$ .03 / \mathrm{Kwh} \times 240$ hours $=\$ 319.46$

Annual electricity cost to run existing grinder onsite $=\$ 62.42$

The cost of electricity in the Tri-Cities is currently $\$ .03 / \mathrm{Kwh}$. The grinder runs on $220 \mathrm{amp}$.

$(.5 \mathrm{HP}+10 \mathrm{HP}+5 \mathrm{HP}) \times 75 \%=11.6 \mathrm{HP} \times .7457 \mathrm{KW} / \mathrm{hp}=8.67 \mathrm{Kwh} \times \$ .03 \times 240$ hours $=$ $\$ 62.42$.

Annual electricity cost to run cuber $=\$ 805.35$

The cost of electricity in the Tri-Cities is currently $\$ .03 / \mathrm{Kwh}$. The average load under normal operating conditions is $75 \%$ of the total 200 hp on the cuber. Costs are based on an operational throughput of 7 tons per hour.

$200 \mathrm{hp} \times 75 \%=150 \mathrm{hp} \times .7457 \mathrm{Kw}=112 \mathrm{Kwh} \times \$ .03 / \mathrm{Kwh} \times 240=\$ 805.35$ 
Annual labor cost to feed weeds through cuber $=\$ 36,000$

Based upon information provided by Warren and Baerg, at $85 \%$ efficiency, 7 tons of cubes are produced per hour.

2 operators $\times \$ 75$ per hour $=\$ 150 /$ hour

$\$ 150 /$ hour $\times 6$ hours $/$ day $=\$ 900 /$ day

$\$ 900 /$ day $\times 5$ days $/$ week $=\$ 4,500 /$ week

$\$ 4,500 /$ week $\times 8$ weeks $/$ year $=\$ 36,000 /$ year

\section{Benefits:}

Annual tumbleweed disposal cost $=\$ 0$

The disposal costs are zero as the tumbleweeds are dumped in inert pits and left for decomposition. Tumbleweeds are no longer burned in the burn pits and therefore there is no air permit required.

Annual labor cost for collection of tumbleweeds $=\$ 0$

The annual labor cost is zero, the tumbleweeds are collected regardless of final disposition or use.

Annual noxious weed control spray cost $=\$ 25,000$

For fiscal year 1996, the "Noxious Weed" budget for Hanford is $\$ 50,000$ to control noxious weeds onsite which is considered a minimal maintenance program. It is estimated that $50 \%$ is for controlling Yellow Starthistle and Russian Knapp Weed.

$50 \%$ divided by $\$ 50,000=\$ 25,000$ annually

Annual cost of a Liquid Propane (LP) $=\$ 3.464$

Natural gas is not available to the $N$ Area where the $K$ Basin pools are located. LP gas from AmeriGas is currently \$.659/gal.

An LP gas heater, running at approximately $90 \%$ efficiency, will consume about .6 gallons/hour of LP to produce 449,498 BTU's/hour.

$\$ .659 /$ gal $\times .6$ gallons/hour $\times 24$ hours/day $\times 365$ days/year $=\$ 3,464 /$ year

Cost of a LP Gas Tank and Heater $=\$ 4,000$ Amortized Annual Cost $=\$ 880$

AmeriGas LP tanks range from 5 gallon $-1,000$ gallon tanks. The 124 gallon tank is $\$ 450$, the 500 gallon tank is $\$ 950$, and the 1,000 gallon tank is $\$ 1,600$. The 500 gallon tank is recommended. The cost of an LP gas heater is approximately $\$ 3,000$.

Installation is an additional $\$ 50$.

Based upon a 20 year life cycle, the annual amortized cost including maintenance and repairs, for the LP gas tank and heater is $\$ 440$. An additional $\$ 2,200$ is expected

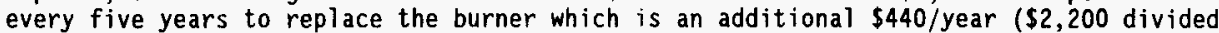
by $5=\$ 440)$. 


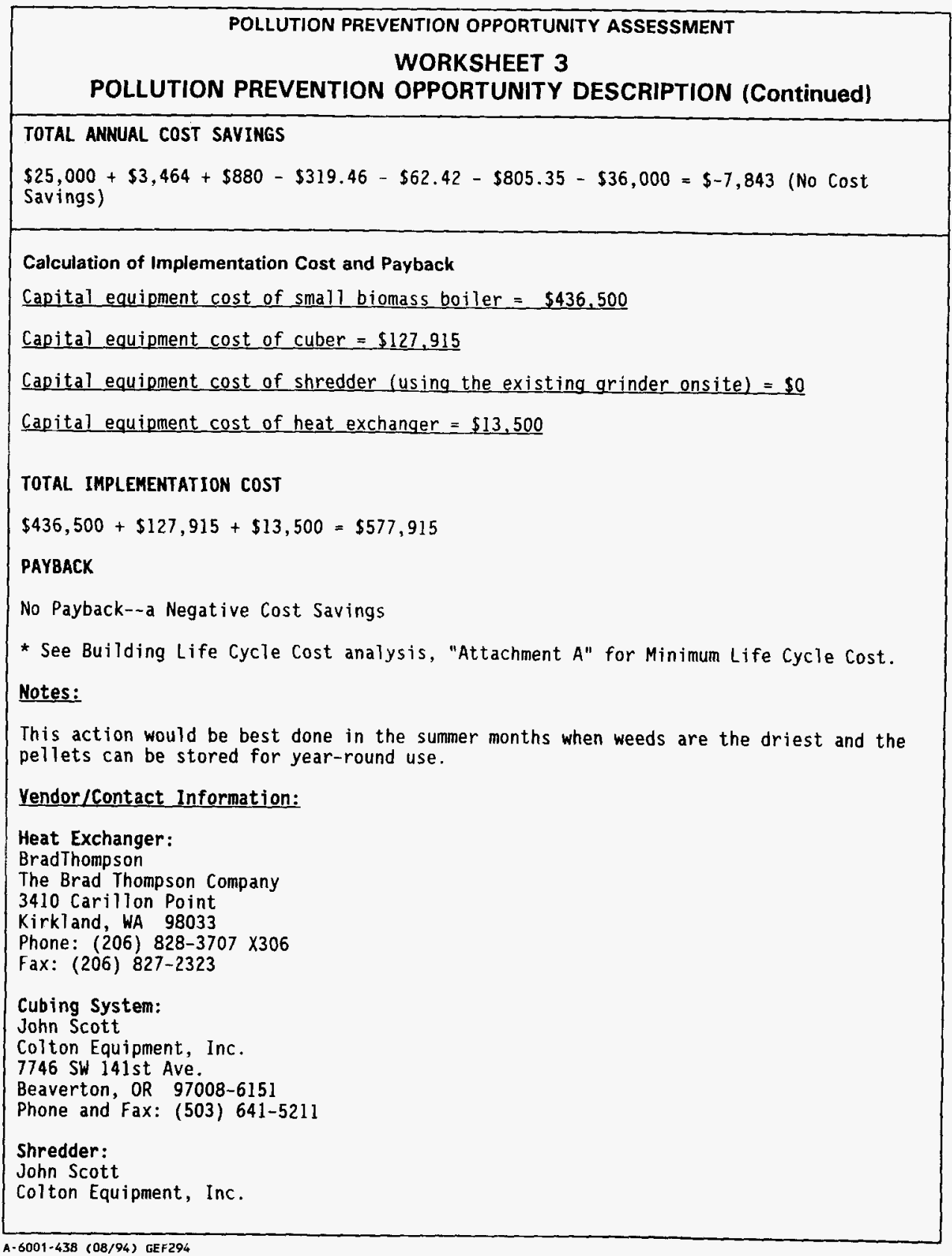


7746 SW 141 st Ave.

Beaverton, OR 97008-6151

Phone and Fax: (503) 641-5211

Botler:

Randy Paterson

Wellons

14440 SW Tualatin-Sherwood Road

P.0. Box 1030

Sherwood, OR 97140-1030

Phone: (503) 625-6131

Fax: (503) 625-5366

Hanford Noxious Weed Program:

Richard Roos

Westinghouse

(509) 373-7480

Hanford Grinder:

Johnnie Young

ICF Kaiser

(509) 373-6272

Hanford Tumbleweed Collection:

Rusty Knight

ICF Kaiser

(509) 376-6654

Scott Angerman

ICF Kaiser

(509) 376-3377

Jerry Maiuri

ICF Kaiser

376-3763 
WORKSHEET 3

POLLUTION PREVENTION OPPORTUNITY DESCRIPTION

Date 04/24/96 P2OA ID Code Energy-1 Facility K Basin Pools

Activity Water Heating Methods for Raising Warm Water Fish Species

P2O No. 2

P20 Title Utilize the Excess Solar Water Heater on the 2750 Roof

\section{Current Practice}

Because this project is in design, there is no current practice. Therefore, Liquid Propane (LP) will be used as the current practice to heat approximately 140,000 gallons of water in the header pool and maintain the temperature between $60-70$ degrees Fahrenheit for optimal fish growth. It is estimated that approximately 449,498 BTU's/hour will be required.

\section{Recommended Action}

Utilize the excess solar water heater from the 2750-E for heating water at the K-Pools. The system (the Sunset by Rheem Manufacturing Company) consists of two tanks each with an 82 gallon capacity. The system $\left(4^{\prime} \times 8^{\prime}\right)$ was in place approximately 15 years. The working pressure is $150 \mathrm{psi}$, the test pressure is $300 \mathrm{psi}$, and the voltage is 120 volts.

The solar system on building 2750-E has not been maintained due to control system failure since its installation in 1980 . Now, the solar system has been disconnected and dismantled. The condition of the solar energy receiver surfaces, heat transfer fluid tubing and reflection/conduction insulating material inside every one of the four collector assemblies is in excellent condition. The condition of the visible tubing is appears to be good. However, there is one area of tubing which will require replacement. Foam insulation is missing from a few feet of tubing and connection. The condition of all the foam insulation is poor due to lack of a white latex protective coating not previously applied to protect the insulation from ultraviolet radiation. The condition of the solar collector housings and mounting braces is also in excellent condition. The plastic film window (cover) is completely gone on all four collectors.

Currently, the heaters are at the Westinghouse Excess yard and the tanks remain in the 2750-E Building.

The upgrades recommended by Rheem Engineering are as follows:

Flush the solar fluid heat transfer reservoir and system. Flush every two years thereafter or when litmus test indicates that contents have passed from neutral to acidic.

If the Thrush solar fluid circulation pump has failed, replace it with a Grundfos pump. One or two in series depending on the static head required to refill the system after draindown.

The plastic film cover as applied originally is no longer recommended by Rheem. Rather, reglaze with Sunlite II paneling. 
WORKSHEET 3

POLLUTION PREVENTION OPPORTUNITY DESCRIPTION (Continued)

Calculation of Waste Reduction and/or Energy Savings

Annual quantity of Liquid Propane (LP) required $=5.256$ gallons

The quantity of LP necessary to maintain the temperature required is approximately .6 gallons/hour running at $90 \%$ efficiency.

.6 gallons/hour $\times 24$ hours/day $\times 365$ days $/$ year $=5,256$ gallons $/$ year

TOTAL WASTE REDUCTION

5,256 gallons LP gas

Calculation of Annual Cost Savings

Benefits:

Annual Cost of a Liquid Propane (LP) $=\$ 3,464$

Natural gas is not available to the $N$ Area where the $K$ Basin pools are located. LP gas from AmeriGas is currentiy \$.659/gal.

An LP gas heater, running at approximately $90 \%$ efficiency, will consume about .6 gallons/hour of LP to produce 449,498 BTU's/hour.

$\$ .659 /$ gal $\times .6$ gallons/hour $\times 24$ hours/day $\times 365$ days/year $=\$ 3,464 /$ year

Cost of a LP Gas Tank and Heater $=\$ 4,000$ Amortized Annual Cost $=\$ 880$

AmeriGas LP tanks range from 5 gallon - 1,000 gallon tanks. The 124 gallon tank is $\$ 450$, the 500 gallon tank is $\$ 950$, and the 1,000 gallon tank is $\$ 1,600$. The 500 gallon tank is recommended. The cost of an LP gas heater is approximately $\$ 3,000$.

Installation is an additional $\$ 50$.

Based upon a 20 year 1 ife cycle, the annual amortized cost including maintenance and repairs, for the LP gas tank and heater is $\$ 440$. An additional $\$ 2,200$ is expected every five years to replace the burner. The cost of an LP gas heater is approximately $\$ 3,000$.

TOTAL ANNUAL COST SAVINGS

$\$ 3,464+\$ 880=\$ 4,344$

Calculation of Implementation Cost and Payback

Implementation Cost of Removing and Reinstalling Solar Water Heater $=\$ 4,000$

Removing and reinstalling the solar water heater is estimated to cost approximately $\$ 4,000$.

Upgrade Project Costs $=\$ 1,205$ 


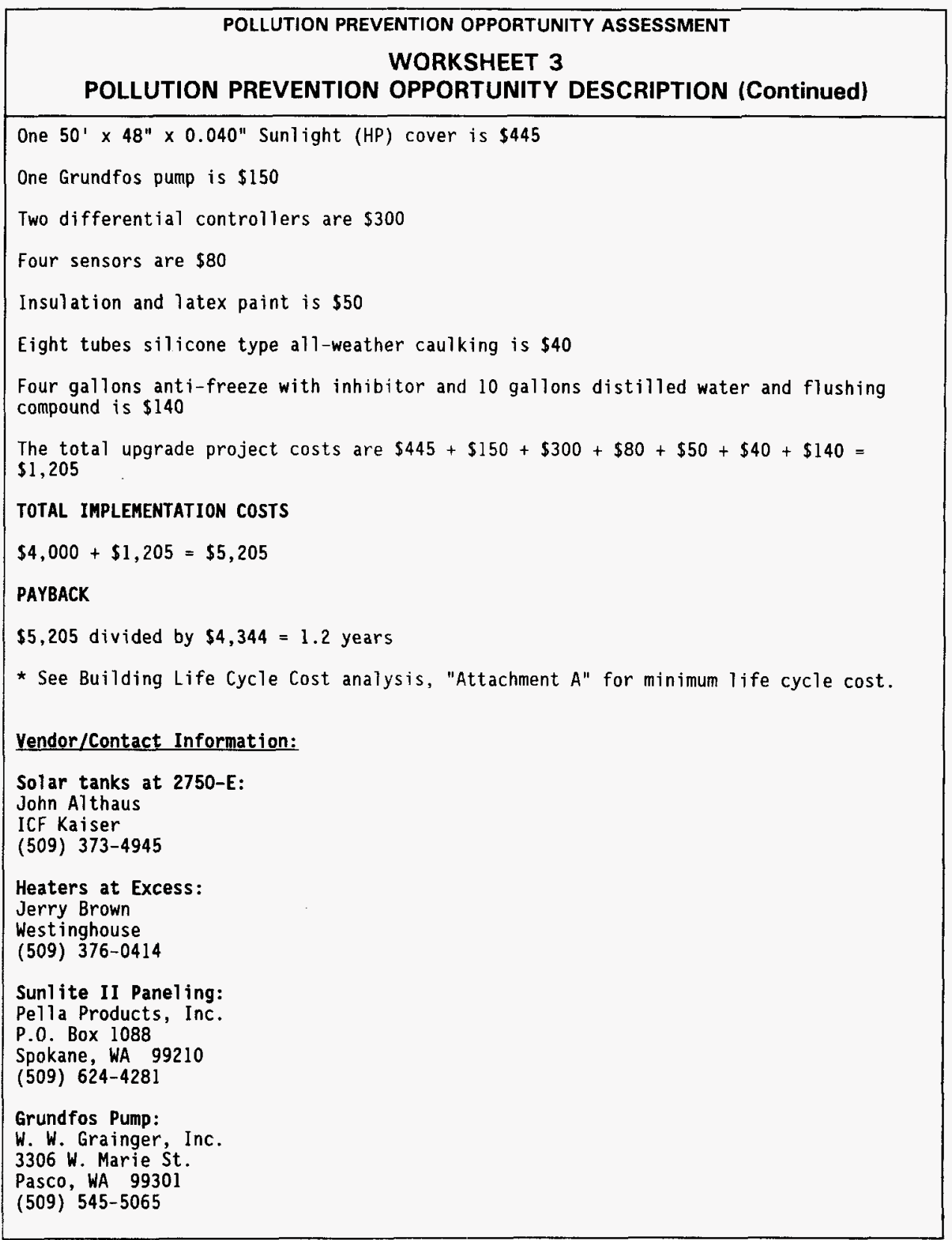




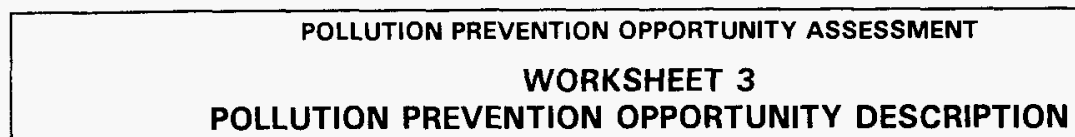

Date 04/24/96 P2OA ID Code K Basin-1 Facility K Basin Pools

Activity Water Heating Methods for Raising Warm Water Fish Species

P2O No. 3

P20 Title Solar Water Heating Panels

\section{Current Practice}

Because this project is in design, there is no current practice. Therefore, Liquid Propane (LP) will be used as the current practice to heat approximately 140,000 gallons of water is the header pool and maintain the temperature between $60-70$ degrees Fahrenheit for optimal fish growth. It is estimated that approximately 449,498 BTU's/hour will be required.

\section{Recommended Action}

Heliocol Solar Panels (Roger Eschenroeder, Hel iocol Solar)

A Heliocol panel converts about $70 \%$ of the energy that falls on it to thermal energy for heating. For Eastern Washington, this represents an average daily energy delivery of about 856 BTU's per square foot of panel area. The Heliocol Solar collector is a heat exchanger which can be used to collect thermal energy as well as to distribute thermal energy.

One Heliocol HC-50 collector (50 sq ft) will produce about 42,800 BTU's/day or about $15,622,000$ BTU's/year. The HC-50 Collector data has the following characteristics:

\section{Size $4^{\prime} \times 12^{\prime}$}

Width $47^{\prime \prime}$

Length 151.5"

Area ( $\mathrm{Sq} . \mathrm{ft})$.

Manifold Diameter 2"

Weight, Dry 22 1bs.

Volume Capacity 3.7 gal.

Max. Working Pressure 90 PSI

Burst Pressure 270 PSI

Recommended Flow 5 GPM

Heliocol collectors are manufactured using "over-molding" process whereby the headers and risers become one piece of plastic--there are no seams or welds. The "over-molded" construction provides 120 PSI operating pressure. This design virtually eliminates wind load and the collectors are certified to withstand $180 \mathrm{MPH}$ winds. The individual tubes also enable the roof to "breathe" which prevents moisture from being trapped under the collector. Since each tube is able to expand and contract independently, cracks and leaks due to wear and tear of thermal expansion and contraction are eliminated. High head pressures are eliminated which protects the collector against clogging. Lower head pressure keeps pumping requirements to a minimum which helps maximize efficiency.

Heliocol collectors offer a twelve year warranty on panels and installation including freeze protection. 
WORKSHEET 3

\section{POLLUTION PREVENTION OPPORTUNITY DESCRIPTION (Continued)}

\section{Calculation of Waste Reduction and/or Energy Savings}

Annual quantity of Liquid Propane (LP) required $=5,256$ qallons

The quantity of LP necessary to maintain the temperature required is approximately .6 gallons/hour running at $90 \%$ efficiency.

.6 gallons/hour $\times 24$ hours $/$ day $\times 365$ days $/$ year $=5,256$ gallons $/$ year

TOTAL ANNUAL WASTE REDUCTION

5,256 gallons LP gas

\section{Calculation of Annual Cost Savings}

Benefits:

Annual Cost of Liquid Propane (LP) $=\$ 3,464$

Natural gas is not available to the $\mathrm{N}$ Area where the K Basin pools are located. LP gas from Amerigas is currently $\$ .659 / \mathrm{gal}$.

An LP gas heater, running at approximately $90 \%$ efficiency, will consume about . 6 gallons/hour of LP to produce 449,498 BTU's/hour.

$\$ .659 /$ gal $\times .6$ gallons/hour $\times 24$ hours/day $\times 365$ days $/$ year $=\$ 3,464 /$ year

Cost of a LP Gas Tank and Heater $=\$ 4,000$ Amortized Annual Cost $=\$ 880$

AmeriGas LP tanks range from $5 \mathrm{gallon}-1,000$ gallon tanks. The 124 gallon tank is $\$ 450$, the 500 gallon tank is $\$ 950$, and the 1,000 gallon tank is $\$ 1,600$. The $500 \mathrm{gallon}$ tank is recommended. The cost of an LP gas heater is approximately $\$ 3,000$.

Installation is an additional $\$ 50$.

Based upon a 20 year 1 ife cycle, the annual amortized cost including maintenance and repairs, for the LP gas tank and heater is $\$ 440$. An additional $\$ 2,200$ is expected every five years to replace the burner The cost of an LP gas heater is approximately $\$ 3,000$.

Cost of a LP Gas Tank $=\$ 950$

AmeriGas LP tanks range from 5 gallon - 1,000 gallon tanks. The 124 gallon tank is $\$ 450$, the 500 gallon tank is $\$ 950$, and the 1,000 gallon tank is $\$ 1,600$. The 500 gallon tank is recommended.

TOTAL ANNUAL COST SAVINGS

$\$ 3,464+\$ 880=\$ 4,344$

Calculation of Implementation Cost and Payback 


\section{POLLUTION PREVENTION OPPORTUNITY ASSESSMENT \\ WORKSHEET 3 \\ POLLUTION PREVENTION OPPORTUNITY DESCRIPTION (Continued)}

Capital Equipment Cost of Solar Panels $=\$ 39,600$

A Helicol HC-50 costs about $\$ 250.00$ per collector. Approximately $120 \mathrm{HC}-50$ 's will be needed for a total capital cost of $\$ 39,600$ including installation costs.

TOTAL IMPLEMENTATION COST

$\$ 39,000$

PAYBACK

$\$ 39,600$ divided by $\$ 4,344=9.1$ years

* See Building Life Cycle Cost analysis, "Attachment A" for minimum life cycle cost.

Vendor/Contact Information:

Solar Panels:

Roger Eschenroeder

Heliocol Solar

13620 49th Street North

Clearwater, FL 34622

Phone: (813) 572-6655

Fax: (813) 572-7922

Liquid Propane Tank:

Amerigas

$204 \mathrm{~N}$ Fruitland

Kennewick, WA 99336

(509) 582-8888

Liquid Propane:

Amerigas

$204 \mathrm{~N}$ Fruit 7 and

Kennewick, WA 99336

(509) 582-8888

Liquid Propane Gas Heater:

Jacobs and Rhodes

$4825 \mathrm{~W}$. Clearwater Avenue

Kennewick, WA 99336

(509) 783-3121 
WORKSHEET 3

POLLUTION PREVENTION OPPORTUNITY DESCRIPTION

Date 06/20/96 P2OA ID Code Energy-1 Facility K Bas in Pools

Activity Water Heating Methods for Raising Warm Water Fish Species

P20 No. $4 \quad$ P20 Title Water Source Heat Pump

\section{Current Practice}

Because this project is in design, there is no current practice. Therefore, liquid Propane (LP) will be used as the current practice to heat approximately 140,000 gallons of water is the header pool and maintain the temperature between $60-70$ degrees

Fahrenheit for optimal fish growth. It is estimated that approximately 449,498

BTU's/hour will be required.

\section{Recommended Action}

Implement a water source heat pump which will pull Columbia River water into a heat exchanger and strip heat from the water and then discharge it back into the river at a reduced temperature. The approximate source water flow and load water flow is 36 GPM with water entering at an average temperature of 50 degrees Fahrenheit. Entering fluid temperatures below 45 degrees Fahrenheit requires an antifreeze solution. The recommended water source heat pump, Model WH/P158-3 available through Total Energy Management, Richland Washington has the following characteristics:

General Performance Data: -Source and load water pressure drop is 11.7 FOH

Cooling Performance Data: -Capacity is 157,563 BTUs/Hour

-Total watts are 7,283

-Energy efficiency ratio is 21.6

-Heat rejection is 182,433 BTUs/Hour

-Source leaving water temperature is 60.1 degrees

Fahrenheit

-Load leaving water temperature is 46.2 degrees Fahrenheit

Heating Performance Data: -Capacity is 137,919 BTUs/Hour

- Total watts are 6,060

-Coefficient of performance is 6.7

- Heat absorption is 117,239 BTUs/Hour

-Source leaving water temperature is 43.5 degrees Fahrenheit

-Load leaving water temperature is 67.7 degrees Fahrenheit

\section{Calculation of Waste Reduction and/or Energy Savings}

Annual quantity of Liquid Propane (LP) required $=5,256$ gallons

The quantity of LP necessary to maintain the temperature required is approximately .6 gallons/hour running at 90\% efficiency.

$.6 \mathrm{gallons} /$ hour $\times 24$ hours $/$ day $\times 365$ days $/$ year $=5,256$ gallons $/$ year .

TOTAL ANNUAL WASTE REDUCTION

5,256 gallons LP gas 


\section{POLLUTION PREVENTION OPPORTUNITY ASSESSMENT \\ WORKSHEET 3 \\ POLLUTION PREVENTION OPPORTUNITY DESCRIPTION (Continued)}

\section{Calculation of Annual Cost Savings}

Costs:

\section{Electricity required to run water pump $=\$ 978$}

Electrical requirements include a minimum circuit ampacity of 48.0 and a maximum fuse size or HACR circuit breaker of 60 . This includes water pump amperage.

$5 \mathrm{hp} \times 0.745 \mathrm{~kW} / \mathrm{hp} \times \$ .03 \mathrm{~kW} / \mathrm{hr} \times 8760 \mathrm{hrs} / \mathrm{yr}=\$ 978$

Benefits:

Annual Cost of Liquid Propane (LP) $=\$ 3,464$

Natural gas is not available to the $N$ Area where the K Basin pools are located. LP gas from AmeriGas is currently $\$ .659 / \mathrm{gal}$.

An LP gas heater, running at approximately $90 \%$ efficiency, will consume about .6 gallons/hour of LP to produce 449,498 BTU's/hour.

$\$ .659 /$ gal $\times .6$ gallons/hour $\times 24$ hours/day $\times 365$ days $/$ year $=\$ 3,464 /$ year

Cost of a LP Gas Tank and Heater $=\$ 4,000$ Amortized Annual Cost $=\$ 880$

AmeriGas LP tanks range from 5 gallon - 1,000 gallon tanks. The $124 \mathrm{gallon}$ tank is $\$ 450$, the 500 gallon tank is $\$ 950$, and the 1,000 gallon tank is $\$ 1,600$. The 500 gallon tank is recommended. The cost of an LP gas heater is approximately $\$ 3,000$.

Installation is an additional $\$ 50$.

Based upon a 20 year 1 ife cycle, the annual amortized cost including maintenance and repairs, for the LP gas tank and heater is $\$ 440$. An additional $\$ 2,200$ is expected every five years to replace the burner The cost of an LP gas heater is approximately $\$ 3,000$.

Cost of a LP Gas Tank $=\$ 950$

Amerigas LP tanks range from 5 gallon - 1,000 gallon tanks. The $124 \mathrm{gallon}$ tank is $\$ 450$, the 500 gallon tank is $\$ 950$, and the 1,000 gallon tank is $\$ 1,600$. The 500 gallon tank is recommended.

TOTAL ANNUAL COST SAVINGS

$\$ 3,464+\$ 880-978=\$ 3,366$

\section{Calculation of Implementation Cost and Payback}

Cost of water source heat pump $=\$ 15,000$

The capital equipment cost for the water source heat pump is approximately $\$ 15,000$ including installation.

TOTAL IMPLEMENTATION COST 


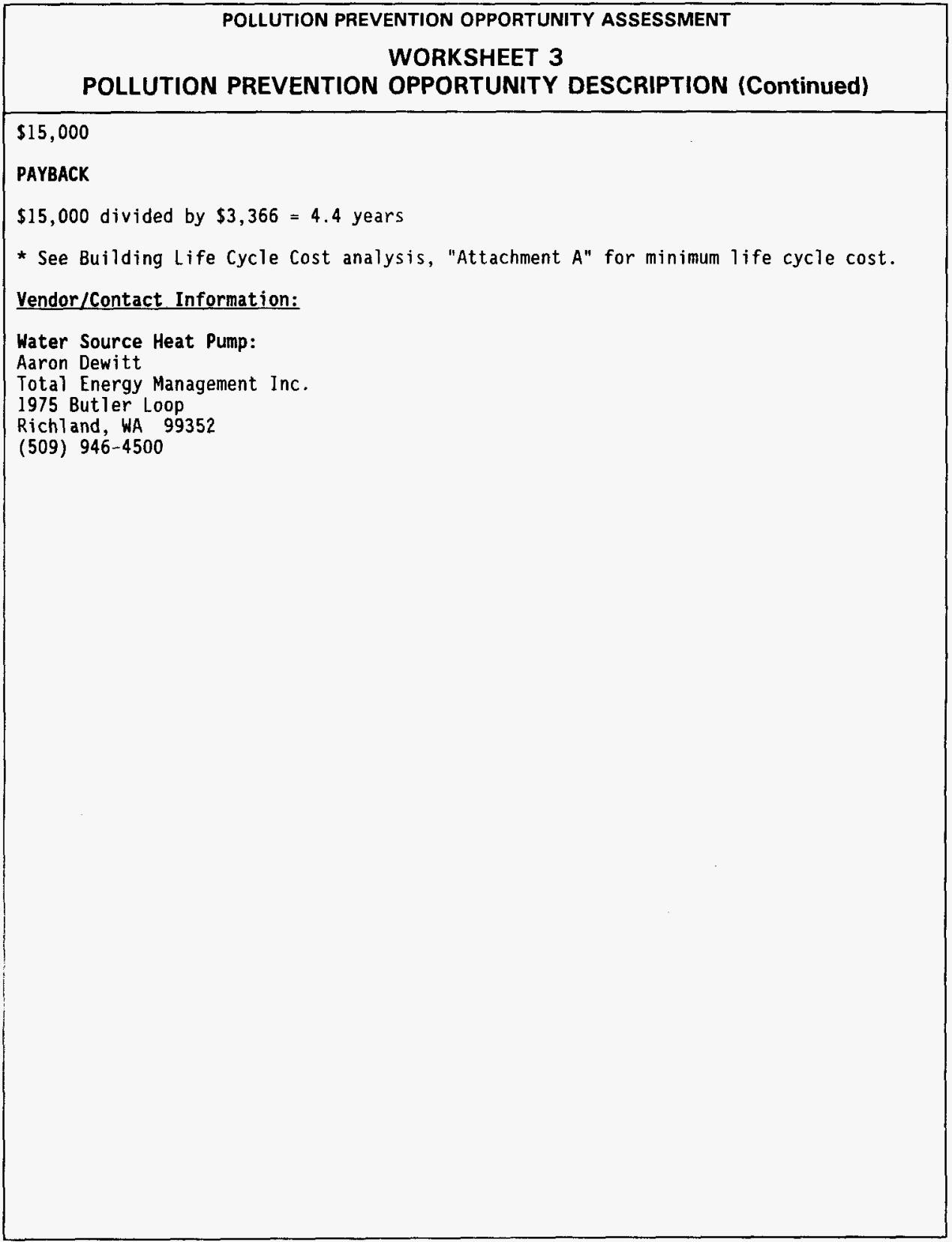




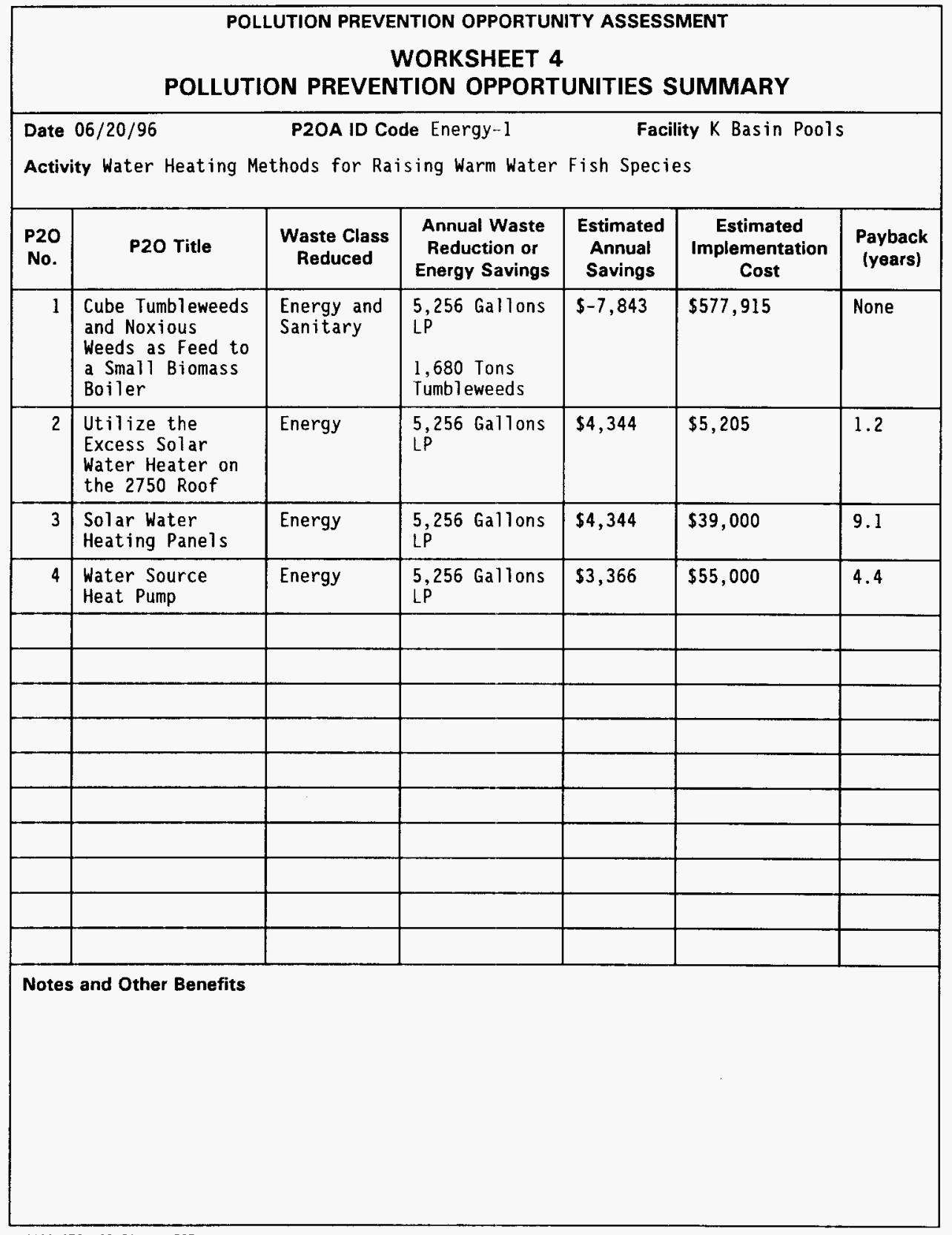


POLLUTION PREVENTION OPPORTUNITY ASSESSMENT

WORKSHEET 5

FINAL SUMMARY

Date 06/20/96 P20A ID Code Energy-1 Facility K Basin Pools

Activity Water Heating Methods for Raising Warm Water Fish Species

\section{Proposed Opportunities and Discussion}

It has been previously demonstrated by the Yakama Indian Nation that large number of fish can be successfully raised in the Hanford 100-K Area water purification pools (K Pools), which are surplus to U.S. Department of Energy needs. Thus, suitable rearing facilities are in place and the Yakama Indian Nation possesses technical fish-rearing skills in the form of a large staff of experienced fish biologists, culturists, and technicians. Therefore, it is fully expected that a Hanford commercial aquaculture facility can significantly contribute to supplying warm-water species for sports fishing purposes and profitable seafood products for the West coast fresh fish market.

Solar technology is safe, clean and efficient. It makes sense, then to heat at least in part with solar heating. Reuse of the existing solar water heater from the 2750 Building provides the greatest payback in close to 1 year. The upgrades to the unit and the associated costs are minimal.

The obvious disadvantage to solar energy is that during cold weather, no matter how big the system is, it won't produce energy. In the winter months, it may be necessary to supplement the solar technology with liquid propane during inclement or very cold weather. Since a constant water temperature is not critical, it may be possible to let the temperature drop some during the 3-4 month period of extremely cold weather. The implementation cost of a liquid propane tank and heater is less than $\$ 4,000$ and the cost for liquid propane is minimal.

Cubing tumbleweeds and noxious weeds is not a viable solution due to the high cost of capital equipment and labor charges. Additionally, National Environmental Policy Act (NEPA) documentation would be required as farming this waste source is potentially a major federal action significantly affecting the quality of the human environment. The NEPA documentation is an added expense not calculated in the payback.

The Heliocol solar panel system has a payback of over 9 years as the initial cost is $\$ 36,000$. A less expensive solar system might be viable--one such as simple as coiled black plastic tubing could provide enough solar energy to heat the water.

A water source heat pump, could provide a good water heating method as the temperature of the Columbia river water is ideal for this type of setup. However, the capital equipment cost and installation are considerably high.

\section{Recommendations and Schedule for Implementation}

obtaining the excess solar heater and associated equipment should be done immediately as the heaters are already at the Westinghouse Excess yard for deployment to another DOE site, another government agency, or the general public. The tanks to the solar heater still remain at the 2750 Building but should also be moved as soon as possible to avoid excess to another organization or possible disposal.

It is further recommended to wait until the fall months to purchase the liquid propane system. During the summer months actual energy consumption data can be calculated to determine if a liquid propane system is necessary. The systems are readily available 


\section{POLLUTION PREVENTION OPPORTUNITY ASSESSMENT \\ WORKSHEET 5 \\ FINAL SUMMARY (Continued)}

from AmeriGas and therefore do not require a long lead time for delivery. 


\section{Building Life Cycle Cost Analysis}

QI filename $=$ FISHP20A.QI

Analysis type $=$ Federal Analysis--Energy Conservation Projects

Project name $=\mathrm{K}$-Basin $\mathrm{F}$ ish P20A

Base Date of Study $=1996$

Service Date $=1996$

Study Period $=20$ years

Discount rate $=4.1 \%$

Inflation rate $=0.00 \%$

Cap replacements and residual values (if any) included as investment costs.

Residual values automatically calculated for capital components.

Residual values automatically calculated for capital replacements.

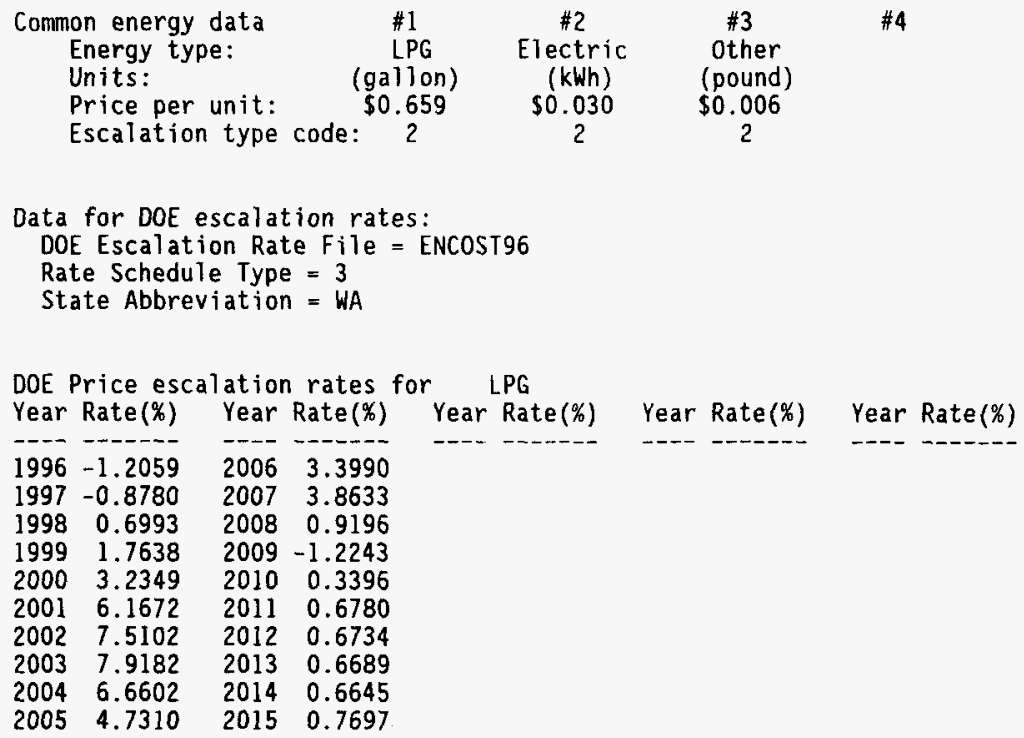

DOE Price escalation rates for Electric

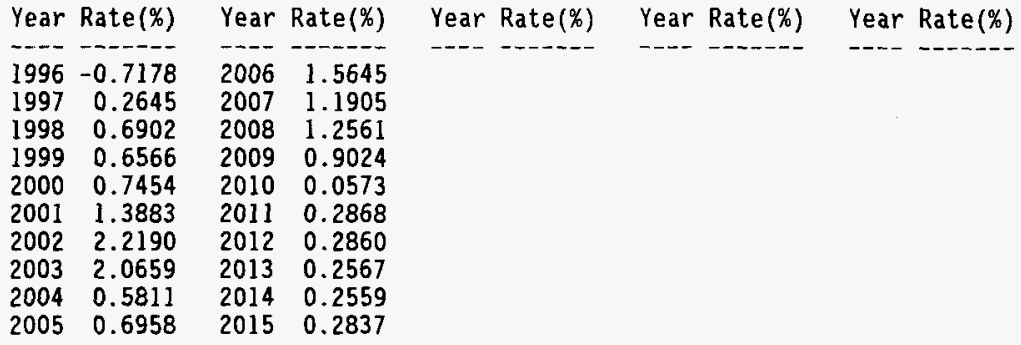

DOE Price escalation rates for other 


\begin{tabular}{rrrrrrr} 
Year Rate(\%) & Year Rate(\%) & Year Rate(\%) & Year Rate(\%) & Year Rate(\%) \\
\hdashline 1996 & -0.7178 & 2006 & 1.5645 & & & \\
1997 & 0.2645 & 2007 & 1.1905 & & & \\
1998 & 0.6902 & 2008 & 1.2561 & & & \\
1999 & 0.6566 & 2009 & 0.9024 & & & \\
2000 & 0.7454 & 2010 & 0.0573 & & & \\
2001 & 1.3883 & 2011 & 0.2868 & & & \\
2002 & 2.2190 & 2012 & 0.2860 & & & \\
2003 & 2.0659 & 2013 & 0.2567 & & & \\
2004 & 0.5811 & 2014 & 0.2559 & & & \\
2005 & 0.6958 & 2015 & 0.2837 & & &
\end{tabular}

Number of alternatives in file $=5$

Number of groups in file $=1$

\begin{tabular}{|c|c|c|c|c|c|c|c|c|c|}
\hline \multirow[b]{2}{*}{$\begin{array}{c}\mathrm{ALT} \\
\#\end{array}$} & \multirow[b]{2}{*}{$\begin{array}{l}\text { AL TERNATIVE } \\
\text { NAME }\end{array}$} & \multirow[b]{2}{*}{$\begin{array}{l}\text { GROUP } \\
\text { CODE }\end{array}$} & \multirow[b]{2}{*}{ 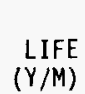 } & \multirow[b]{2}{*}{$\begin{array}{l}\text { INITIAL } \\
\operatorname{COST}(\$)\end{array}$} & \multicolumn{2}{|c|}{$\begin{array}{c}\text { CAPITAL } \\
\text { REPLACEMENTS }\end{array}$} & \multirow{2}{*}{$\begin{array}{c}\text { ANNUAL } \\
\text { OM\&R } \\
\operatorname{COST}(\$\end{array}$} & \multicolumn{2}{|c|}{ NON-ANNUAL OM\&R } \\
\hline & & & & & $\begin{array}{l}\text { REPL } \\
\text { FREQ* }\end{array}$ & $\begin{array}{l}\text { ICEMENTS } \\
\operatorname{COST}(\$)\end{array}$ & & FREQ* & $\operatorname{cosT}(\$)$ \\
\hline 3 & $\begin{array}{l}\text { Baseline-L } \\
\text { Biomass He } \\
\text { Solar-New } \\
\text { Solar-Reus } \\
\text { Heat Pump- }\end{array}$ & & & $\begin{array}{r}4000 \\
15000\end{array}$ & $\begin{array}{l}20 / 0 \\
20 / 0 \\
20 / 0\end{array}$ & 0 & $\begin{array}{r}4 \\
370 \\
4\end{array}$ & & \\
\hline
\end{tabular}

*FREQ $=$ Frequency of occurrence (in years/months)

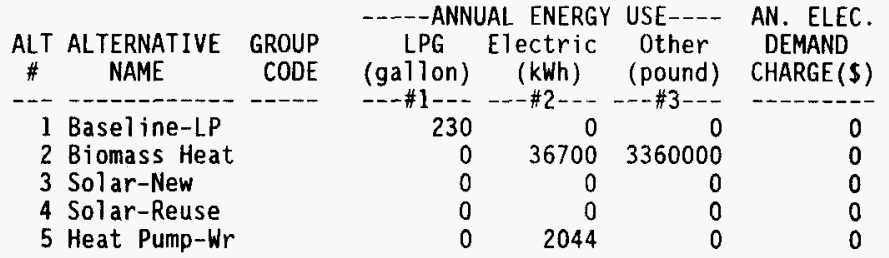


Figure 1

The $R$ Basin Warm water Fish Rearing Program Conceptual Design

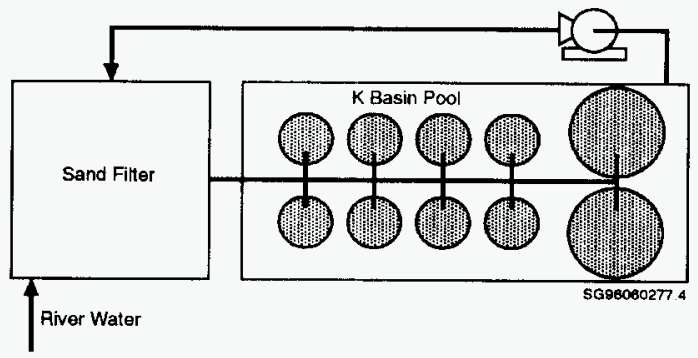

